IZA DP No. 8913

The Earnings and Employment Losses Before Entering the Disability System

María Cervini-Plá

Judit Vall Castelló

March 2015 


\title{
The Earnings and Employment Losses Before Entering the Disability System
}

\author{
María Cervini-Plá \\ EQUALITAS and EDReG \\ Judit Vall Castelló \\ CRES, Universitat Pompeu Fabra \\ and IZA
}

Discussion Paper No. 8913

March 2015

IZA

P.O. Box 7240

53072 Bonn

Germany

Phone: +49-228-3894-0

Fax: +49-228-3894-180

E-mail: iza@iza.org

Any opinions expressed here are those of the author(s) and not those of IZA. Research published in this series may include views on policy, but the institute itself takes no institutional policy positions. The IZA research network is committed to the IZA Guiding Principles of Research Integrity.

The Institute for the Study of Labor (IZA) in Bonn is a local and virtual international research center and a place of communication between science, politics and business. IZA is an independent nonprofit organization supported by Deutsche Post Foundation. The center is associated with the University of Bonn and offers a stimulating research environment through its international network, workshops and conferences, data service, project support, research visits and doctoral program. IZA engages in (i) original and internationally competitive research in all fields of labor economics, (ii) development of policy concepts, and (iii) dissemination of research results and concepts to the interested public.

IZA Discussion Papers often represent preliminary work and are circulated to encourage discussion. Citation of such a paper should account for its provisional character. A revised version may be available directly from the author. 


\title{
ABSTRACT \\ The Earnings and Employment Losses Before Entering the Disability System
}

\begin{abstract}
Although a number of papers in the literature have shown the employment and wage differences between disabled and non-disabled individuals, not much is known about the potential employment and wage losses that disabled individuals suffer before being officially accepted into the disability insurance system (DI). Therefore, in this paper we distinguish between individuals that enter the DI system due to a working accident (sudden health shock) and individuals that become disabled due to an ordinary illness to identify the differences in employment and wages between these two groups before they are officially accepted into the DI system. We combine matching models and difference-in-difference and we find that the wage (employment) growth patterns of both groups of workers become significantly different three (six) years before entering the DI system. More specifically, our estimates suggest that one year before entering the system, there is a difference of 27 Euros/month in the wages of the two groups (3\% of average wage) as well as a 10 percentage point difference in employment probabilities.
\end{abstract}

JEL Classification: J31, I13

Keywords: disability system, employment, wage loss

Corresponding author:

Judit Vall Castelló

Center for Research in Health and Economics (CRES)

Department of Economics and Business

Pompeu Fabra University

Ramon Trias Fargas, 25-27

08005 Barcelona

Spain

E-mail: judit.vall@upf.edu 


\section{Introduction}

There is now strong empirical evidence showing that disabled individuals have lower employment rates and earnings than their non-disabled counterparts everywhere in Europe (OECD, 2009). Apart from establishing the existence of a negative correlation between disability and labour market outcomes, a number of authors have also tried to estimate the causal effect of the onset of a disabling condition on employment and wages. The results of these studies are ambiguous as some of the papers find no evidence of a reduction in income due to a disability (Lechner \& Vazquez-Alvarez (2011) for Germany or Walker and Thomson (1996) for the UK) while some others find moderate to strong losses in annual earnings after the onset of a disabling condition (Kofi Charles (2003), Mok et al. (2008) and Jolly (2011) for the USA, Kidd et al. (2000) and Contoyannis and Rice (2001) for the UK, Halla and Zweimüller (2013) for Austria) ${ }^{1}$. For Spain, Garcia-Gomez and Lopez-Nicolás (2006) estimate that a health event reduces the income of disabled workers in 1648 Euros/year. Additionally, heterogeneity seems to play an important role in this type of studies as variables that capture the socioeconomic status of the individual prove determinant in explaining the labour market outcomes after becoming disabled. In this line, Lundborg et al. (2011) highlight that, in Sweden, the reduction in labour earnings is stronger for low educated and older individuals. This group of papers that focuses on the effects of a disabling condition on labour market outcomes typically measure disability with self-reported information on health status. In these settings it is difficult to rule out the existence of endogeneity between the onset of a disabling condition and labour market outcomes. A recent stand of the literature has focused on the labour market effects of disability using a more objective measure of disability status; the receipt of disability benefits. Those papers have clearly established a negative causal effect of benefit receipt on labour force participation (Bound, 1989; Von Wachter, Song and Machester, 2011; Maestas, Mullen and Strand, 2013; Chen and Van Der Klaauw, 2008; Marie and Vall-Castello, 2012; French and Song, 2014). For the Spanish case, Cervini et al. (2012) find that individuals receiving disability benefits in Spain earn around 293-342 Euros/month less than similar individuals without a disability.

\footnotetext{
${ }^{1}$ See also Malo et al. (2012) for a comparative study of the wage differentials for diferent types of disabled workers across European countries.
} 
Therefore, most of the previous literature analysing the labour market disadvantages for disabled workers has focused on the employment and earnings losses as a result of selfreporting the onset of a disabling condition or as a result of the receipt of disability benefits. A less studied question is whether disabled workers are already suffering from a disadvantage in terms of labour market outcomes before the official recognition of the disabling condition. Thus, in this paper we use a large administrative dataset and a clearly exogenous health event to estimate the wage and employment losses eight years before individuals are accepted into the DI system. More specifically, we compare the earnings and employment status (during the eight years before DI) of individuals who will become disabled due to a working accident to those that will become disabled due to an ordinary illness. The argument behind this comparison relies on the fact that an accident represents a sudden health shock while an ordinary illness appears in a more progressive manner. Therefore, individuals suffering from an ordinary illness are arguably spending a number of years with the disability until the severity of the condition is strong enough to be legally accepted into the DI system. We match individuals in the two groups on a rich set of observable characteristics eight years before the receipt of the benefits and apply a difference-in-difference model to estimate the earnings and employment losses of individuals suffering from a progressive deterioration of their health status. We argue that, after matching individuals in the two groups, the only important difference between these workers is that one will become disabled by a sudden health shock while the other will suffer from a progressive deterioration of his/her health condition until entering DI. Therefore, we attribute the observed differences in the wage growth and employment paths of these two similar workers to the progressivity of the disabling condition of one of them. Indeed, in our data both groups of workers exhibit similar wage growth paths (employment rates) until three (six) years before entering DI. One year before entering the system, we estimate a difference of 27 Euros/month in the wages of the two groups (3\% of the average wage) and a 10 percentage point difference in employment probabilities. We also report important heterogeneity effects according to the age of the worker, his/her professional category as well as the type of disability benefits that he/she will receive (total or partial disability, which is a proxy for the severity of the condition).

The only two papers in the literature that focus on employment and earnings losses before becoming disabled are Kofi Charles (2003) and Mok et al. (2008). In the later 
paper, the authors estimate a $66.8 \%$ drop in annual earnings in the year of onset of the disability and a $49.3 \%$ drop in the year before onset. Although the estimated effects in both papers are much larger than the ones we report here, there are at least two main reasons that can explain these differences in results. First, both Kofi Charles (2003) and Mok et al. (2008) use a self-reported measure of disability while we use the receipt of DI benefits (which occurs after going through a medical examination) as our measure of disability. Therefore, we believe that we capture a more exogenous measure of disability. Second and more importantly, although the papers by Kofi Charles and Mok et al. include individual fixed effects in their models, they cannot control for endogeneity (if individuals report a disability as a result of experiencing a drop in earnings) and their results may be biased upwards (as the authors recognised in their papers). Our econometric approach, matching individuals that will suffer from an accident to individuals that will experience a common illness and applying a differencein-difference technique, is able to provide results that are not subject to endogeneity problems. Therefore, we believe that we are able to present the first unbiased measure in the literature of the earnings and employment losses for disabled individuals before they can access the DI system.

In most developed economies with a well-functioning social security system, disability benefits are calculated as a function of previous earnings. Similarly, eligibility to the system typically also requires a minimum number of years of employment (contributions). Therefore, the results of our paper are important for policy-makers as they suggest that taking the last years of labour market experience as a base to calculate the amount and eligibility of DI benefits may not reflect the typical wage and employment pattern of individuals without a disability as those suffering from an ordinary illness are already experiencing lower employment probabilities and receiving lower wages well before entering DI.

This paper is organized as follows. Section 2 presents the characteristics of Spanish DI System. Section 3 explains the dataset used and our sample selection. Section 4 shows our hypothesis and descriptive statistics. Section 5 explains the empirical method used in the paper. Finally, section 7 presents the results and section 8 concludes. 


\section{The Spanish DI System}

The Social Security defines the permanent contributive disability insurance as the economic benefits to compensate the individual for losing a certain amount of wage or professional earnings when affected by a permanent reduction or complete loss of his/her working ability due to the effects of a pathologic or a traumatic process derived from an illness or an accident.

In order to capture the different situations in which a person can be after suffering from a disabling condition, the Spanish Social Security administration uses a classification of three main degrees of disability that depend on the working capacity lost: ${ }^{2}$ partial disability if the individual is still capable of developing a different job or professional activity, total disability if the individual is impaired for the development of any kind of job and severe disability if the individual needs the assistance of a third person to develop the essential activities of daily living. ${ }^{3}$

The eligibility requirements and the pension amount depend on the source of the disability (ordinary illness, work related or unrelated accident or occupational illness), the level of the disability and the age of the onset of the disabling condition. Table A1 in the Appendix summarizes the main parameters of both the eligibility criteria and the pension formula.

The total amount of the pension is obtained by multiplying a percentage, which varies depending on the type of pension and the degree of disability (as shown in the last rows of Table 1) to the regulatory base, which depends on the source of the disability and on previous salaries. ${ }^{4}$ The percentage is $55 \%$ or $75 \%$ for partial disability beneficiaries, $100 \%$ for total disability and $150 \%$ for severe disability.

\section{Database and Sample Selection}

We use the Continuous Sample of Working Lives ("Muestra Continua de Vidas Laborales", MCVL) which is a microeconomic dataset based on administrative records provided by the Spanish Social Security Administration. It contains a random sample of

\footnotetext{
${ }^{2}$ There is a fourth degree of disability benefits (permanent limited disability) but this type of benefits is already extinguished and it only consists on a one-time lump-sum payment.

${ }^{3} 57 \%$ of claimants are in the partial disability system, $40 \%$ of claimants in the total disability system and $3 \%$ are severely disabled.

${ }^{4}$ Benefit=regulatory base $*$ percentage
} 
$4 \%$ of all the individuals who, at some point during 2010, had contributed to the social security system (either by working or being on an unemployment scheme) or had received a contributory benefit. ${ }^{5}$ The random sample selected contains over one million people.

There is information available on the entire employment and pension history of the workers, including the exact duration of employment, unemployment and disability benefit spells, and for each spell, several variables that describe the characteristics of the job or the unemployment/disability benefits spell. There is also some information on personal characteristics such as age, gender, nationality and level of education.

In our sample we select everybody that enters the DI system either with a partial or total disability between 1996 and 2010 and we follow them from 8 years before entering the system until the year in which they are officially accepted into DI. ${ }^{6} \mathrm{We}$ also restrict the sample to include only individuals between the ages of 35 and 65 at the time of entering the DI system. We have chosen age 35 because we need to observe the labor market history of these workers 8 years before entering DI. We have chosen age 65 because individuals in the disability system are automatically transferred to the old-age system when they turn age 65 . We select workers both in the partial and total disability system as we are interested in the employment and earnings losses that these workers suffer before entering the system (even if total disability individuals cannot work once they are in DI).

In order to identify the employment and earnings losses that disabled workers experience before being accepted into the DI System, we distinguish between individuals that become disabled due to a working accident from individuals that become disabled due to an ordinary illness. The selected sample contains 33,202 individuals (252,496 person-year observations in total), 2,337 of them become disabled due to a working accident while 30,865 are disabled due to an ordinary illness.

\footnotetext{
${ }^{5}$ This means that the only individuals that are missing from this database are those who were inactive in 2010 and did not receive any kind of contributory benefit (such as disability, orphan, widow, etc.). Furthermore, the sample is representative for 2010 but, as exit from the disability system is extremely low $(0.01 \%)$, we are confident that the sample is also representative for the other years included in the analysis.

${ }^{6}$ Before being accepted into the permanent DI system, the individual needs to spend some time in the temporary disability system while he/she receives the prescribed treatment. There is a maximum period of 18 months that each individual can spend in temporary DI. Therefore, we exclude the 18 months prior to the observed entry into permanent DI to make sure that we are capturing the labour market situation of the individual before going through any of the two DI systems.
} 
With respect to the labor market trajectory of these workers during the eight years preceding the entrance into the DI system, we have considered an individual as employed if he/she is observed as working on the 15th of each month.

\section{Hypothesis and Descriptive Statistics}

As explained above, our interest lies in the estimation of the employment and earnings losses for disabled individuals before they are officially acknowledge as such. In order to do that, we will distinguish between individuals that access the DI system due to an ordinary illness from those that access the DI system due to a working accident. We will examine the differences in the employment and wage growth pattern of these two groups of workers eight years before entering the DI system. The idea behind this comparison, as showed in Figure 1, is that individuals suffering from a working accident experience a sudden health shock which gives them access to the DI system while individuals suffering from an ordinary illness experience a progressive deterioration of their health status. Thus, individuals with an ordinary illness need to spend some time before reaching the necessary health threshold to get access to the DI system. As wages grow over time, by comparing the wage growth path of individuals who suffer from a working accident to individuals that suffer from an ordinary illness we will be able to identify how much wages failed to increase in the group of workers with an ordinary illness due to the progressivity of the disabling condition that deteriorates their productivity levels and, therefore, their employment prospects and their wages.

Figure 1. Expected differences in wage and employment growth patterns between individuals suffering from an ordinary illness and individuals suffering from a working accident. 


\section{If ordinary \\ illness}

\section{Disability is} progressive
Suffer from

employment and

wage loss before DI

\section{If working}

accident

\section{Sudden health \\ shock}

\section{No employment \\ and wage loss \\ before DI}

Looking at Figure 2 and Figure 3 we can already get a first impression of the hypothesis developed above. As we can observe in Figure 2, even though individuals who will suffer from a working accident have a lower monthly wage eight years before being accepted into DI, the rate of wage growth is higher for this group of workers. In fact, Figure 2 shows that, (around) three years before being accepted into the DI system, the group of individuals suffering from a working accident already enjoys a considerably higher wage than the group of workers with an ordinary illness.

Figure 2. Monthly real wages before entering the DI system.

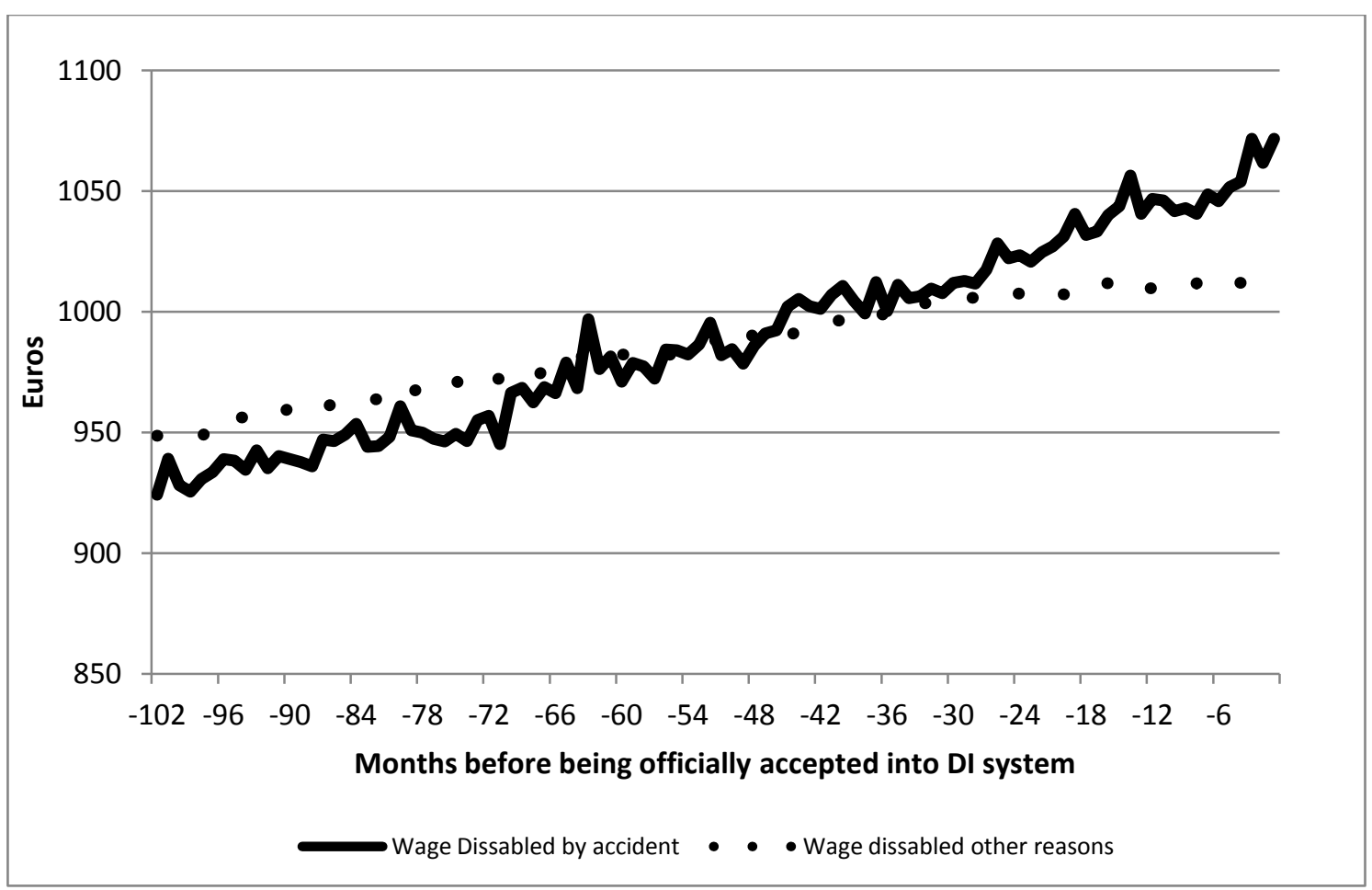


Similarly, Figure 3 plots the evolution of employment probabilities from eight years before entrance into DI. In general terms, employment probabilities are higher for individuals who become disabled by an accident. Eight years before DI, employment trends show a parallel evolution between the two groups. However, when we get closer to the date of entry into the system, employment probabilities for individuals who will become disabled by an accident increase at a stable rate while employment probabilities for those who will become disabled for other reasons remain constant.

Figure 3. Monthly employment probabilities before entering the DI system.

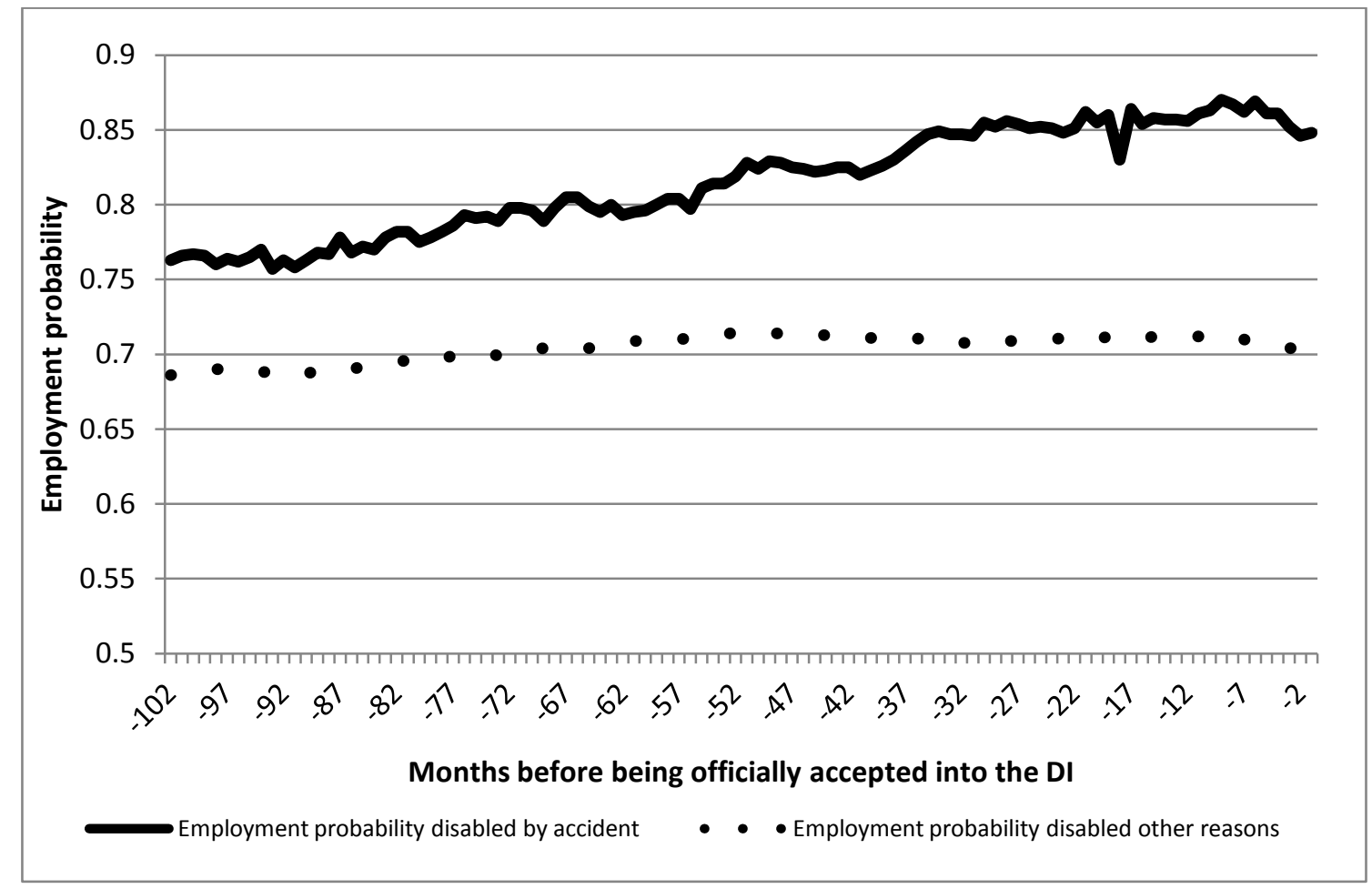

Of course, this graphical evidence does not allow us to automatically attribute these differences in the wage growth path and employment probabilities to the fact that the disabled due to an ordinary illness are already disabled (and thus, incurring in an earnings and employment loss) before entering the DI system whereas individuals that become disabled due to an accident are not disabled before DI (and thus, do not incur in an earnings or employment loss). Alternatively, there is another potential explanation of this evolution as the differences in employment probability and wage growth rates can be due to the fact that the source of the disability is also capturing two different types of individuals with different employment and wage patterns. For example, the observed 
differences could be caused by differences in education levels, age of the workers or sectors of the economy where they are employed.

As far as these differences between individuals in the two groups are observable, we can control for these other potential sources of wage growth variation so that we are able to isolate the variation that is due to the fact of suffering from a disabling condition before being able to enter the DI system.

In that sense, to get a first impression of the similarity of workers in these two groups, Table 1 presents descriptive statistics of the two dependent variables (wages and employment probability) and our explanatory variables according to the source of the disabling condition.

Table 1. Descriptive statistics of the variables included in the model.

\begin{tabular}{|c|c|c|c|}
\hline Characteristics & $\begin{array}{c}\text { Disabled by } \\
\text { accident }\end{array}$ & \begin{tabular}{|c|} 
Disabled \\
other reasons
\end{tabular} & $\begin{array}{l}\text { t-test equal } \\
\text { mean }\end{array}$ \\
\hline Wage (in Euros) & 946.58 & 922.58 & $-5.11 * * *$ \\
\hline Employment probability & 84.30 & 73.60 & $-3.60 * * *$ \\
\hline Age disability (mean) & 48.97 & 51.86 & $17.29 * * *$ \\
\hline \multicolumn{4}{|l|}{$\operatorname{Sex}(\%)$} \\
\hline Men & 86.99 & 67.23 & $-19.97 * * *$ \\
\hline \multicolumn{4}{|l|}{ Nationality (\%) } \\
\hline Spanish workers & 97.00 & 98.89 & $7.93 * * *$ \\
\hline \multicolumn{4}{|l|}{ Education $(\%)$} \\
\hline Primary & 47.41 & 47.44 & -0.65 \\
\hline Secondary & 38.28 & 34.99 & $-3.71 * * *$ \\
\hline Tertiary & 12.92 & 15.55 & $3.07 * * *$ \\
\hline Post-graduate & 1.39 & 2.02 & $1.99 * *$ \\
\hline \multicolumn{4}{|l|}{ Professional Category (\%) } \\
\hline Unskilled laborers & 78.98 & 66.00 & $-14.63 * * *$ \\
\hline $\begin{array}{l}\text { Other semi-skilled workers, } \\
\text { skilled and semi-skilled clerks }\end{array}$ & 15.24 & 24.84 & $5.39 * * *$ \\
\hline $\begin{array}{l}\text { Engineers and graduates, chief } \\
\text { and departmental heads }\end{array}$ & 5.78 & 9.16 & $2.89 * * *$ \\
\hline \multicolumn{4}{|l|}{ Sector of Activity (\%) } \\
\hline Agriculture & 7.79 & 9.43 & 0.78 \\
\hline Industry & 54.41 & 36.07 & $-16.19 * * *$ \\
\hline Construction & 16.23 & 18.36 & $-2.73 * *$ \\
\hline Trade, Transport and Hotels & 5.35 & 7.61 & 1.96 \\
\hline Public Administration & 15.48 & 25.94 & $3.29 * * *$ \\
\hline Finance & 0.75 & 2.55 & 1.33 \\
\hline \multicolumn{4}{|l|}{ Type of Contract (\%) } \\
\hline Part-time & 4.53 & 8.5 & 4.91 \\
\hline
\end{tabular}




\begin{tabular}{|l|l|l|l|} 
& & & \\
\hline Number of individuals & 2,337 & 30,865 & \\
\hline
\end{tabular}

As we can see in Table 1, the composition of individuals in the two groups is somewhat different in several of the variables analyzed. Therefore, we will apply a matching technique to make sure that we are comparing pairs of individuals that are as similar as possible.

\section{Empirical Model}

We apply three methods in order to distinguish the difference in the wage path and employment probability between individuals that become disabled due to a working accident and those that become disabled due to an ordinary illness.

First of all, we follow a similar approach than Charles (2003) to identify the wage path before the individual enters the DI system and we estimate the following regression:

$W_{i t}=\alpha_{i}+\beta X_{i t}+\tau D A_{i t} d_{i t}+\vartheta D N A_{i t} d_{i t}+\varepsilon_{i t}$

where: $W_{i t}$ represents the log of averaged monthly earnings of person $\mathrm{i}$ in year $\mathrm{t}, X_{i t}$ are the control variables: education, professional category, age at $t=-8$, sector of activity, gender, nationality and part-time contract. The variables of interest are the two binary variables: $D A_{i t}$ and $D N A_{i t}$. In particular, $D A_{i t}$ takes value 1 if the individual enters the DI system due to accident and $D N A_{i t}$ takes value 1 if the individual enters the DI system due to an ordinary illness. Both variables are multiplied by $d_{i t}$, that measures the distance before the date of entrance in the DI system and ranges from -8 ...to 0 .

With this regression we can compare the path of earnings and employment for these two groups of workers.

Although we include a set of control variables in the regression, we could still argue that working accidents are concentrated in some type of activities or some type of workers (some evidence of these differences has been shown in the descriptive statistics in Table 1). Therefore, we employ a second method which tries to take this differences into account; Propensity Score Matching (PSM). With this method we want to estimate 
how much employment probabilities and wages change, on average, for those individuals who will become disabled due to an accident, compared to the hypothetical state of becoming disabled due to other reasons. One of the main problems in measuring this change is that the individual actually experiences only one type of disability. Therefore, we make use of matching methods to allow for the counterfactual approach, associated with treatment effects techniques for policy evaluation.

Formally, let $D=1,0$ indicate if the individual is actually treated or not. In our case, if the individual becomes disabled by an accident or not. Let $X$ be the set of observed characteristics and $W_{1 i}$ and $W_{0 i}$ be the potential variable of interest if the individual is treated or non-treated, respectively. The notion of "potential" is used to emphasize that only one of $W_{1 i}$ or $W_{0 i}$ is observed for every individual in the sample.

In this context we want to measure the Average Treatment Effect on the Treated (ATET) that is given by the following expression:

$$
A T E T=\vartheta=E\left\lfloor W_{1 i}-W_{0 i} \mid D_{i}=1\right\rfloor=E\left\lfloor W_{1 i} \mid X, D_{i}=1\right\rfloor-E\left\lfloor W_{0 i} \mid X, D_{i}=1\right\rfloor
$$

Clearly $\vartheta$ is not identified by the data, since we observe each individual in one of the possible states in each moment in time. Therefore, we do not observe the counterfactual. If we assume that the probability of becoming disabled by an accident is random, we could solve this problem by using the control group, those who become disabled by an ordinary illness, as a counterfactual. However, as outlined above, it is likely that those types of accidents occur in certain professions or economic sectors more than in others.

Therefore, our empirical strategy relies on the fact that we have sufficient information on the characteristics of the individual and the type of job that he/she has before entering the DI system. In this context, we use the PSM to create subgroups where the treated and control individuals do not differ eight before being accepted in DI and then we use different matching techniques to compare the individual in the treated group that is most similar to an individual in the control group. ${ }^{7}$

In particular, our conditional independence assumption is:

$$
\left(W_{1 i}, W_{0 i}\right) \perp D \mid X
$$

\footnotetext{
${ }^{7}$ See Heckman and Horz (1989), Heckman, Ichimura and Todd (1997) and Blundell and Costa Dias (2002) are some of the articles that explain how to evaluate certain treatments using matching procedures.
} 
This strong assumption is known as selection on observables and was introduced by Rubin $(1973,1974)$ and Rosenbaum and Rubin $(1983,1984)$.

The idea is that using this method, the ATET is identified under the assumption that observable controls and the pre-treatment outcomes include all factors that determine both the probability that an individual becomes disabled by accident or by other reasons, as well as his potential employment probability and wage in the absence of this type of disability.

Therefore, in an attempt to relax this strong hypothesis, the third method that we use to estimate the effect of interest is a combination of Difference-in-Differences (DID) with PSM. More specifically, we estimate a DID model using weights obtained from the PSM (see García-Gómez et al. (2013) for a detailed explanation of the approach). The main idea of this new technique is to use PSM to obtain a comparable set of treated and control individuals and estimate a DID model to control for fixed unobservable characteristics. Essentially, by running this weighted DID regression we weaken the identifying assumption of the matching estimator (conditional independence assumption). Therefore, this technique only requires that, conditional on observables, in the absence of the shock the evolution (not levels) of employment probabilities and wages before and after the shock would have been the same for the treated and their matched controls (Heckman et al. (1997); Blundell and Costa-Dias (2002)).

Following the rational of this technique, our treated group is formed by individuals who are officially non-disabled in $t=-8, t=-7, t=-6, \ldots, t=-1$, and become officially disabled (that is, enter the DI system) by an exogenous disability shock (accident) in $t=0$.

As a control or comparison group we want similar individuals in $t=-8$, the moment in which we construct the propensity score. Those individuals continue being nonofficially disabled in $t=-7, t=-6, \ldots, t=-1$, when they are accepted into the DI system due to an ordinary illness.

We match individuals in the treated and control groups with the propensity score in $t=-$ 8 , where both individuals were officially non-disabled. We use: age at $t=-8$, education, professional category, sector of activity, gender, part-time contract, nationality, region and wages in $t=-8$ as explanatory variables. 


\section{Results}

\subsection{Effect on wages}

In this section we try to quantify the effects of being non-officially disabled on wages. In order to do that we compare the wage pattern of individuals that enter into the DI system due to an accident with that of individuals that enter into the DI system due to an ordinary illness during the eight years prior to being accepted into the DI system.

Table 2 shows the results of the estimation of equation (1) for wages, i.e the wage path for both types of disability during the 8 years before entering the DI system. Here we only present the coefficient of the interaction between the two main dummies (the type of disability they have at $t=0$ ) and the distance to the event (getting access into the DI system). The results of the full regression are presented in table A2 in the Appendix. The reference year is -8 ( 8 years before the individual enters the DI system). ${ }^{8}$

Table 2: Wage path for both disability types. 8 years before entering DI.

\begin{tabular}{|c|c|c|}
\hline Years since DI & Disabled by accident & Disabled other reasons \\
\hline-7 & 0.020 & $0.017 * * *$ \\
& $(0.013)$ & $(0.004)$ \\
\hline-6 & $0.030 * * .037 * * *$ \\
& $(0.012)$ & $0.004)$ \\
\hline-5 & $0.055^{* * *}$ & $0.055 * * *$ \\
& $(0.012)$ & $(0.004)$ \\
\hline-4 & $0.076 * * *$ & $0.072 * * *$ \\
& $(0.012)$ & $(0.004)$ \\
\hline-3 & $0.11)^{* * *}$ & $0.094 * * *$ \\
& $(0.012)$ & $(0.004)$ \\
\hline-2 & $0.135 * * *$ & $0.112 * * *$ \\
& $(0.012)$ & $(0.003)$ \\
\hline-1 & $\mathbf{0 . 1 7 2} * * *$ & $\mathbf{0 . 1 2 5} * * *$ \\
& $(0.011)$ & $(0.003)$ \\
\hline
\end{tabular}

Note: Dependent variable: log of monthly earnings. Standard errors in parentheses.

As we can see in Table 2, real wages for both types of disabled workers increase every year compared to the reference year. However, from 4 years before entering DI, wages of individuals that will become disabled by an accident grow faster than wages of individuals that will become disabled due to an ordinary illness. From 4 years before

\footnotetext{
${ }^{8}$ We choose to show the results from 8 years before entering the DI system because, as it can be seen in Figures $2 \& 3$, the differences in both employment and wages between the two groups of individuals only start appearing from 6 years before getting access into DI.
} 
entering the DI system, individuals that become disabled due to an ordinary illness show a disadvantage in terms of wages in the labor market and their position deteriorates relative to individuals that will suffer from a sudden health shock.

For example, in $t=-1$, i.e. one year before individuals enter the system (compared to the situation at $t=-8$ ) wages of workers who will become disabled by accident, controlling for characteristics, are on average 33.4 euros per month higher than wages of individuals who will become disabled for other reasons. ${ }^{9}$

In order to make sure that we are comparing individuals as similar as possible, in a second specification we estimate ATET effects following Becker and Ichino (2002), Abadie and Imbens (2002) and Abadie et al. (2004). In order to apply this method, we first estimate the propensity score (the probability of being in the treatment group) by a probit specification (as we have two possible states; individuals that will become disabled by an accident versus individuals that will become disabled by other reasons). As we have explained before, we match individuals in the treated and control groups with the propensity score in $t=-8$, where both individuals were officially non-disabled. As explanatory variables we use all the variables available in the administrative dataset: age of disability, education, professional category, sector of activity, gender, part-time contract, nationality, region and wages at $t=-8$. The specification passes the "balancing hypothesis". This means that there are no systematic differences in observable characteristics between the treated and control groups once we condition on the propensity score. After that, we match treated and control individuals using the nearest neighbor matching approach. ${ }^{10}$

Table 3 presents the estimates of ATET on wages at $t=-7, t=-6, \ldots, t=-1$. As the dependent variable we use the monthly average wage. In particular, we sum the wage

\footnotetext{
${ }^{9}$ On average wages at $t=-8$ were about 878 euros per month for those individuals who will become disabled by an accident and 885 euros per month for disabled due to ordinary illness. Then, if wages of workers that become disabled by an accident increased by $17.2 \%$ in $t=-1$ this gives an average wage of 1029 euros per month. On the other hand, the increase in wages for the disabled by ordinary illness is $12.5 \%$ which gives an average wage of 995.6 euros in $t=-1$ Therefore, that gives us a difference of 33.4 euros.

${ }^{10}$ As there is no element (a priori) to chose one matching technique over the others we show the results of the same model but using kernel matching and stratification matching in Table A3 in the Appendix.
} 
received in all months worked and then we divide this wage by the total number of months worked. ${ }^{11}$

Table 3: Average difference of monthly wages between disabled by accident and disabled by ordinary illness. 8 years before entering DI.

\begin{tabular}{|c|c|c|}
\hline $\begin{array}{c}\text { Years since } \\
\text { DI }\end{array}$ & $\begin{array}{c}\text { Propensity Score } \\
\text { Matching }\end{array}$ & $\begin{array}{c}\text { Propensity Score } \\
\text { Matching with DID }\end{array}$ \\
\hline-7 & 2.45 & -1.52 \\
& $(15.29)$ & $(7.49)$ \\
\hline-6 & -7.73 & -10.44 \\
& $(15.69)$ & $(9.55)$ \\
\hline-5 & -3.19 & -1.54 \\
& $(15.99)$ & $(10.46)$ \\
\hline-4 & 3.22 & 1.21 \\
& $(16.09)$ & $(11.11)$ \\
\hline-3 & 15.04 & $17.22 *$ \\
& $(16.26)$ & $(11.52)$ \\
\hline-2 & $\mathbf{1 0 . 3 1} *$ & $\mathbf{8 . 2 8} *$ \\
& $(16.90)$ & $(12.37)$ \\
\hline-1 & $\mathbf{3 0 . 0 3} * *$ & $\mathbf{2 6 . 9 8} * *$ \\
& $(17.34)$ & $(12.69)$ \\
\hline
\end{tabular}

Note: Money figures are expressed in 2010 euros. Bootstrapped standard errors in parentheses. Treated and control individuals are matching using the nearest neighbor matching approach.

As shown in the Table 3 three to eight years before entering the DI system differences in earnings between the two groups are very small and insignificant once we control for observable characteristics. However, once we get closer to the moment in which they become officially disabled we begin to observe an increased wage gap. More specifically, in $t=-1$, using the Propensity Score matching method, the gap amounts to almost 30 Euros/month on average. This result is very similar to the 33.4 Euros wage gap that we obtained in the previous section using separate regressions for both groups. In any case, even if the results of the two estimation methods are quantitatively very

\footnotetext{
${ }^{11}$ We do not use wages but a proxy for wages, the contributory base, over which the contributions to the Social Security administration are calculated and paid. As it often occurs with Social Security records, the difference between contributions and wages is that contributions are top- and bottom-coded, that is, they are censored. Although for the entire MCVL this is a significant problem, as Bonhomme and Hospido (2009) mention such an issue is likely not to be empirically relevant in our case as our sample does not include neither top nor bottom wages earners (bottom earners are typically concentrated in the noncontributory DI system).
} 
similar we prefer the results of the matching model as it allows us to compare two individuals that are more similar in observed characteristics.

Finally, in the last column of Table 3 we follow García-Gómez et al. (2013) and we compare the impact of disability on wages using a combination of PSM with DID. The results obtained are slightly lower but in the same direction to those obtained when we only use PSM. As shown in this last column, differences in wages of the two groups are only significant from three years before entering DI. For $t=-1$, the earnings gap is almost 27 Euros/month on average. This result is very close than the one obtained using only PSM. This earnings gap represents $3 \%$ of the average wage of individuals who will become disabled due to an ordinary illness. ${ }^{12}$

However, by looking only at wages, we are missing another potentially very important effect of disability on labor market outcomes. Non-officially disabled individuals could also be penalized by losing their jobs instead of by earning lower wages way before they are officially accepted into the DI system. Therefore, in the following section we analyze the effects of disability on employment.

\subsection{Effects on employment probability}

Table 4 reports the results of the same ATET model than the one for wages but with employment as the dependent variable. As it can be observed in the first column of Table 4, when we estimate the effects with a PSM workers that will become disabled due to an accident experience significantly higher probabilities of employment than individuals with an ordinary illness as soon as five years before entering the DI system. The coefficient can be interpreted as the percentage point difference in the probability of working between individuals in the treatment (disabled by an accident) and control group (disabled due to ordinary illness). In the year before entering DI, $t=-1$, workers who will enter the DI system due to an accident at $t=0$, have a probability of working of around 8.8 percentage points greater that of workers who will enter the DI system due to an ordinary illness.

\footnotetext{
12 The average wage for individuals in our sample that will enter the DI system due to an ordinary illness is 922.5 Euros/month.
} 
Table 4: Difference in employment probabilities between disabled by accident and disabled by ordinary illness. 8 years before entering DI.

\begin{tabular}{|c|c|c|}
\hline $\begin{array}{c}\text { Years since } \\
\text { DI }\end{array}$ & $\begin{array}{c}\text { Propensity score } \\
\text { matching }\end{array}$ & $\begin{array}{c}\text { Propensity score } \\
\text { matching with DID }\end{array}$ \\
\hline-7 & 0.013 & 0.024 \\
& $(0.008)$ & $(0.017)$ \\
\hline-6 & 0.012 & $\mathbf{0 . 0 2 3} * *$ \\
& $(0.009)$ & $(0.008)$ \\
\hline-5 & $\mathbf{0 . 0 3 8} * * *$ & $\mathbf{0 . 0 4 9} * * *$ \\
& $(0.008)$ & $(0.009)$ \\
\hline-4 & $\mathbf{0 . 0 4 3} * * *$ & $\mathbf{0 . 0 5 4} * * *$ \\
& $(0.008)$ & $(0.010)$ \\
\hline-3 & $\mathbf{0 . 0 6 0} * * *$ & $\mathbf{0 . 0 7 2} * * *$ \\
& $(0.008)$ & $(0.010)$ \\
\hline-2 & $\mathbf{0 . 0 8 6} * * *$ & $\mathbf{0 . 0 9 7} * * *$ \\
& $(0.007)$ & $(0.010)$ \\
\hline-1 & $\mathbf{0 . 0 8 8} * * *$ & $\mathbf{0 . 0 9 9} * * *$ \\
& $(0.007)$ & $(0.011)$ \\
\hline
\end{tabular}

Note: Bootstrapped standard errors in parentheses. Treated and control individuals are matching using the nearest neighbor matching approach.

In the last column of Table 4 we report results of the estimation combining PSM and DID. Again coefficients can be interpreted as the percentage point difference in the probability of working between individuals who enter the DI system due to an accident and those who enter the system due to ordinary illness. Our results show that individuals that will experience an accident present significantly greater employment probabilities as soon as 6 years before entering DI. More specifically, one year before entering the system, individuals who will suffer from an accident have a probability of working 10 percentage points greater than those who will enter the system due to an ordinary illness. $^{13}$

\section{Heterogeneous effects}

The incidence of non-official disability on wages and employment may very well differ along several individual dimensions such as age, professional category or the degree of

\footnotetext{
${ }^{13}$ As before, the results of the estimation using kernel matching as well as stratification matching are reported in Table A4 in the Appendix.
} 
disability (total or partial). In order to explore the existence of heterogeneous effects along these dimensions in this section we estimate our preferred specification, PSM with DID and the Nearest Neighbour Matching approach, for several categories of workers.

In order to analyze the heterogeneity that arises from age, we estimate our model for three different age groups at the time of entering DI: those under 45 , those between 45 and 55 and those older than 55 years old. Table 5 shows the results obtained for the different age groups. We can see that the average wage gap is much greater (65 Euros/month) for younger workers and the gap also appears much earlier (as soon as six years before entering DI) for this group of workers. We do not find any significant employment gap for workers above age 55 although the employment gap for this group of individuals appears much earlier than for the rest of the population (six years before entering DI). Thus, the older group of workers seems to be more penalized for their disability in employment probabilities rather than in wages whereas the younger group of workers is more penalized with lower wages.

Table 5: Heterogeneous effects wages and employment by age groups.

\begin{tabular}{|c|c|c|c|c|c|c|c|}
\hline & \multicolumn{7}{|c|}{ Age } \\
\hline & \multicolumn{3}{|c|}{ Wages } & \multicolumn{4}{|c|}{ Employment } \\
\hline DI & $<45$ & $45-55$ & $>55$ & $<45$ & $45-55$ & $>55$ & \\
\hline-7 & $\begin{array}{r}12.14 \\
(13.92)\end{array}$ & $\begin{array}{r}14.63 \\
(11.42)\end{array}$ & $\begin{array}{l}-20.12 \\
(14.74)\end{array}$ & $\begin{array}{r}0.026 \\
(0.016)\end{array}$ & $\begin{array}{r}0.021 \\
(0.012)\end{array}$ & $\begin{array}{r}0.010 \\
(0.011)\end{array}$ & \\
\hline-6 & $\begin{array}{r}43.44 \\
(16.67)\end{array}$ & $\begin{array}{r}-10.58 \\
(14.74) \\
\end{array}$ & $\begin{array}{r}-51.93 \\
(19.06) \\
\end{array}$ & $\begin{array}{r}0.004 \\
(0.017) \\
\end{array}$ & $\begin{array}{r}0.014 \\
(0.013) \\
\end{array}$ & $\begin{array}{r}\mathbf{0 . 0 3 0} \\
(0.014) \\
\end{array}$ & \\
\hline-5 & $\begin{array}{r}\mathbf{4 7 . 5 6} * * \\
(19.56)\end{array}$ & $\begin{array}{r}-2.99 \\
(15.41) \\
\end{array}$ & $\begin{array}{l}-14.58 \\
(19.53) \\
\end{array}$ & $\begin{array}{r}0.035 \\
(0.018) \\
\end{array}$ & $\begin{array}{r}\mathbf{0 . 0 3 2} * \\
(0.014)\end{array}$ & $\begin{array}{r}\mathbf{0 . 0 4 1} \\
(0.014) \\
\end{array}$ & \\
\hline-4 & $\begin{array}{r}\mathbf{4 5 . 4 3} * * \\
(20.98)\end{array}$ & $\begin{array}{r}7.73 \\
(17.20)\end{array}$ & $\begin{array}{r}3.78 \\
(20.39)\end{array}$ & $\begin{array}{l}\mathbf{0 . 0 4 7} \text { ** } \\
(0.020)\end{array}$ & $\begin{array}{r}0.026 \\
(0.015)\end{array}$ & $\begin{array}{r}\mathbf{0 . 0 4 7} \\
(0.016)\end{array}$ & \\
\hline-3 & $\begin{array}{r}44.09 \text { ** } \\
(21.02)\end{array}$ & $\begin{array}{r}9.60 \\
(16.55) \\
\end{array}$ & $\begin{array}{r}-9.14 \\
(21.10) \\
\end{array}$ & $\begin{array}{r}\mathbf{0 . 0 5 6} * * \\
(0.020)\end{array}$ & 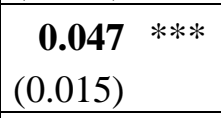 & $\begin{array}{r}\mathbf{0 . 0 5 9} \\
(0.016) \\
\end{array}$ & $* * *$ \\
\hline-2 & $\begin{array}{r}\mathbf{4 0 . 2 2} * \\
(22.47)\end{array}$ & $\begin{array}{r}15.23 \\
(17.88) \\
\end{array}$ & $\begin{array}{r}-15.59 \\
(20.63) \\
\end{array}$ & $\begin{array}{r}\mathbf{0 . 0 9 6} * * * \\
(0.020)\end{array}$ & $\begin{array}{r}\mathbf{0 . 0 7 8} * * * \\
(0.016)\end{array}$ & $\begin{array}{r}\mathbf{0 . 0 6 5} \\
(0.017) \\
\end{array}$ & $* * *$ \\
\hline-1 & $\begin{array}{r}\mathbf{6 5 . 3 7} * * * \\
(23.31)\end{array}$ & $\begin{array}{r}\mathbf{3 8 . 3 7} \\
(18.58)\end{array}$ & $\begin{array}{r}2.45 \\
(21.74) \\
\end{array}$ & $\begin{array}{r}\mathbf{0 . 1 0 3} * * * \\
(0.021) \\
\end{array}$ & $\begin{array}{r}\mathbf{0 . 0 7 4} \text { *** } \\
(0.017)\end{array}$ & $\begin{array}{r}\mathbf{0 . 0 7 4} \\
(0.017) \\
\end{array}$ & $* * *$ \\
\hline $\mathrm{N}$ & 7,774 & 12,304 & 13,124 & 7,774 & 12,304 & 13,124 & \\
\hline
\end{tabular}


Note: Money figures are expressed in 2010 euros. Bootstrapped standard errors in parentheses. $\mathrm{N}$ is the number of person-year observations for each subgroup.

In Table 6 we analyze the heterogeneity that comes from different professional categories and, as it can be observed, the wage gap is only significant for unskilled workers. Similarly, employment losses for individuals suffering from a progressive disability begin earlier also for the group of unskilled laborers (six years before entrance into DI). Although one year before entering the system the employment loss is stronger for skilled workers, the differences in the probability of working for skilled workers only become significant three years before DI.

Table 6: Heterogeneous effects wages and employment by professional category.

\begin{tabular}{|c|c|c|c|c|c|c|}
\hline \multirow{3}{*}{$\begin{array}{c} \\
\text { Years } \\
\text { since } \\
\text { DI } \\
\end{array}$} & \multicolumn{6}{|c|}{ Professional Category } \\
\hline & \multicolumn{3}{|c|}{ Wages } & \multicolumn{3}{|c|}{ Employment } \\
\hline & $\begin{array}{l}\text { Unskilled } \\
\text { laborers }\end{array}$ & $\begin{array}{l}\text { Semi-skilled } \\
\text { workers }\end{array}$ & $\begin{array}{c}\text { Skilled } \\
\text { Workers }\end{array}$ & $\begin{array}{l}\text { Unskilled } \\
\text { laborers }\end{array}$ & $\begin{array}{c}\text { Semi-skilled } \\
\text { workers }\end{array}$ & $\begin{array}{c}\text { Skilled } \\
\text { Workers }\end{array}$ \\
\hline-7 & $\begin{array}{l}-1.11 \\
(7.74)\end{array}$ & $\begin{array}{c}6.05 \\
(20.33)\end{array}$ & $\begin{array}{c}45.92 \\
(59.21)\end{array}$ & $\begin{array}{c}0.022 \\
(0.008)\end{array}$ & $\begin{array}{c}0.026 \\
(0.020)\end{array}$ & $\begin{array}{c}0.036 \\
(0.038)\end{array}$ \\
\hline-6 & $\begin{array}{c}-16.10 \\
(9.75)\end{array}$ & $\begin{array}{l}-27.84 \\
(29.89)\end{array}$ & $\begin{array}{l}102.31 \\
(87.35)\end{array}$ & $\begin{array}{cc}\mathbf{0 . 0 1 9} & * * \\
(0.009) & \\
\end{array}$ & $\begin{array}{c}0.040 \\
(0.026)\end{array}$ & $\begin{array}{c}0.078 \\
(0.052)\end{array}$ \\
\hline-5 & $\begin{array}{c}-4.41 \\
(10.98)\end{array}$ & $\begin{array}{l}-11.78 \\
(33.40)\end{array}$ & $\begin{array}{c}-10.17 \\
(111.37)\end{array}$ & $\begin{array}{cc}\mathbf{0 . 0 4 4} & * * * \\
(0.010) & \\
\end{array}$ & \begin{tabular}{|cc}
$\mathbf{0 . 0 5 5}$ & $*$ \\
$(0.027)$ &
\end{tabular} & $\begin{array}{c}0.076 \\
(0.056)\end{array}$ \\
\hline-4 & $\begin{array}{c}7.79 \\
(11.85) \\
\end{array}$ & $\begin{array}{c}32.41 \\
(38.40)\end{array}$ & $\begin{array}{c}17.17 \\
(117.11)\end{array}$ & $\begin{array}{cc}\mathbf{0 . 0 4 4} & * * * \\
(0.010) & \\
\end{array}$ & $\begin{array}{|cc|}\mathbf{0 . 0 7 7} & * * \\
(0.029) & \\
\end{array}$ & $\begin{array}{c}0.092 \\
(0.059)\end{array}$ \\
\hline-3 & $\begin{array}{c}20.31 \\
(12.09)\end{array}$ & $\begin{array}{c}53.79 \\
(39.45) \\
\end{array}$ & $\begin{array}{c}47.13 \\
(120.55)\end{array}$ & \begin{tabular}{cc|}
$\mathbf{0 . 0 6 1}$ & $* * *$ \\
$(0.011)$ & \\
\end{tabular} & \begin{tabular}{|cc}
$\mathbf{0 . 1 1 5}$ & $* * *$ \\
$(0.033)$ & \\
\end{tabular} & $\begin{array}{cc}\mathbf{0 . 1 4 5} & * * \\
(0.059) & \\
\end{array}$ \\
\hline-2 & $\begin{array}{c}\mathbf{1 9 . 1 2} \\
(12.74)\end{array}$ & $\begin{array}{c}18.30 \\
(45.47)\end{array}$ & $\begin{array}{c}83.86 \\
(125.37)\end{array}$ & $\begin{array}{cc}\mathbf{0 . 0 8 7} & * * * \\
(0.011) & \end{array}$ & $\begin{array}{|cc|}\mathbf{0 . 1 2 0} & * * * \\
(0.034) & \\
\end{array}$ & $\begin{array}{c}\mathbf{0 . 1 6 3} \\
(0.062)\end{array}$ \\
\hline-1 & $\begin{array}{cc}\mathbf{3 1 . 2} & * * \\
(12.37) & \\
\end{array}$ & $\begin{array}{c}-3.28 \\
(50.88) \\
\end{array}$ & $\begin{array}{c}151.41 \\
(137.61) \\
\end{array}$ & $\begin{array}{|cc|}\mathbf{0 . 0 8 7} & * * * \\
(0.011) & \\
\end{array}$ & $\begin{array}{|cc|}\mathbf{0 . 1 1 5} & * * * \\
(0.033) & \\
\end{array}$ & $\begin{array}{ll}\mathbf{0 . 1 5 9} & * * \\
(0.064) & \\
\end{array}$ \\
\hline $\mathrm{N}$ & 21,027 & 7,838 & 4,337 & 21,027 & 7,838 & 4,337 \\
\hline
\end{tabular}

Note: Money figures are expressed in 2010 euros. Bootstrapped standard errors in parentheses. $\mathrm{N}$ is the number of person-year observations for each subgroup.

Finally, Table 7 presents the differences in employment and wage losses between individuals that will become disabled due to an accident and those that will become disabled due to an ordinary illness according to the type of disability benefits that they will receive once they enter the DI system (total or partial). The degree of disability 
benefits, which can be partial or total, is set according to the severity of the disabling condition. We can see that the wage gap is only significant for workers that will become totally disabled and the amount of this gap is greater than in the previous results (97 Euros/month, which is $10.5 \%$ of the average wage). We do not find any significant wage gap for partial disability beneficiaries. However, we do find a significant difference in employment probabilities for both types of individuals from five years before entering DI although the employment loss is stronger for those workers that will become totally disabled. These results reinforce the idea that a progressive deterioration of the health status is accompanied by a wage and employment loss for some years before entering the DI system (as compared to the wage and employment path of individuals suffering from an accident). These losses are stronger for individuals in worst health condition (total disability).

Table 7: Heterogeneous effects wages and employment by type of disability

\begin{tabular}{|c|c|c|c|c|}
\cline { 2 - 5 } \multicolumn{1}{c|}{} & \multicolumn{4}{c|}{ Type of disability } \\
\cline { 2 - 6 } \multicolumn{1}{c|}{$\begin{array}{c}\text { Years } \\
\text { since } \\
\text { DI }\end{array}$} & \multicolumn{2}{c|}{ Wages } & \multicolumn{2}{c|}{ Employment } \\
\hline-7 & -22.25 & -6.63 & 0.050 & 0.021 \\
& $(24.77)$ & $(7.41)$ & $(0.028)$ & $(0.008)$ \\
\hline-6 & 4.86 & -12.10 & 0.062 & 0.018 \\
& $(30.99)$ & $(9.60)$ & $(0.033)$ & $(0.009)$ \\
\hline-5 & 43.64 & -4.83 & $\mathbf{0 . 1 0 9} * * *$ & $\mathbf{0 . 0 4 4} * * *$ \\
& $(40.90)$ & $(10.67)$ & $(0.033)$ & $(0.010)$ \\
\hline-4 & 39.88 & 5.06 & $\mathbf{0 . 1 0 4} * * *$ & $\mathbf{0 . 0 4 1} * * *$ \\
& $(43.27)$ & $(11.49)$ & $(0.034)$ & $(0.011)$ \\
\hline-3 & $73.49 *$ & 3.42 & $\mathbf{0 . 1 3 6} * * *$ & $\mathbf{0 . 0 5 4} * * *$ \\
& $(41.74)$ & $(11.79)$ & $(0.032)$ & $(0.011)$ \\
\hline-2 & $\mathbf{8 0 . 6 3} *$ & 4.47 & $\mathbf{0 . 1 1 7} * * *$ & $\mathbf{0 . 0 8 2} * * *$ \\
& $(44.09)$ & $(12.61)$ & $(0.036)$ & $(0.011)$ \\
\hline-1 & $\mathbf{9 7 . 2 6} * *$ & 13.79 & $\mathbf{0 . 1 3 7} * *$ & $\mathbf{0 . 0 8 6} * * *$ \\
& $(38.65)$ & $(12.98)$ & $(0.035)$ & $(0.012)$ \\
\hline & & & & \\
\hline $\mathrm{N}$ & 11,867 & 21,335 & 11,867 & 21,335 \\
\hline
\end{tabular}

Note: Money figures are expressed in 2010 euros. Bootstrapped standard errors in parentheses. $\mathrm{N}$ is the number of person-year observations for each subgroup. 


\section{Conclusions}

In the literature it has been widely assessed that individuals suffer from both reduced wages as well as lower employment probabilities once they become disabled and enter the disability system. However, a less studied question is whether these loses are already present for disabled workers before they are actually accepted into the DI system. Therefore, in this paper we try to shed some light to this question by estimating the extent to which workers are already suffering from reduced wages before being officially recognized as disabled and, thus, before receiving the corresponding benefits. As it has been well-documented, the relationship between disability and labor market outcomes is difficult to estimate due to the existence of endogeneity problems, as assessing the moment in which the individual first suffers from a disability is not a trivial issue. In order to overcome this problem, we make use of a large microeconomic dataset from the Spanish Social Security administration and apply matching models combined with difference-in-difference to compare the annual earnings and employment growth of individuals who will enter the DI system due to a working accident to those that will enter the system due to an ordinary illness. We argue that the comparison of the labour market outcomes of these two groups of workers eight years before they are accepted in the DI system gives us an unbiased estimate of the effects of disability on wages and employment for non-official disabled individuals. The idea behind this argument is that individuals suffering from a sudden health shock, such as an accident, are not disabled before entering DI. On the other hand, as ordinary illnesses tend to appear in a more progressive manner, individuals suffering from an ordinary illness are presumably spending a number of years with the disabling condition before being legally accepted in the DI system. We use this distinction to apply a matching combined with a difference-in-difference technique to compare the wage growth and employment pattern of two individuals with similar observable characteristics eight years before entering the DI system. We argue that, after matching individuals on a number of observable characteristics eight years before entering the system and controlling for fixed unobservable characteristics with the DID, the only important difference between these two workers is that one will become disabled by an accident while the other will suffer from a progressive deterioration of his/her health condition until the moment of being accepted into the 
DI system. Therefore, we attribute the observed differences in the wage growth and employment path of these two similar workers to the progressivity of the disabling condition for individuals with an ordinary illness.

Our results show that the wage growth patterns of both groups of workers become significantly different three years before entering the DI system. One year before entering the system, we estimate a difference of 27 Euros/month in the wages of the two groups. This quantity represents $3 \%$ of the average wage of disabled individuals in Spain. Differences in employment probabilities are quantitatively more important; our estimates suggest that employment differences between the two groups of workers become significantly different as soon as six years before entering the DI system. One year before entering DI, individuals that will become officially disabled due to an ordinary illness have a 10 percentage points lower probability of working than individuals that will enter the system due to an accident. We also report important heterogeneity effects for younger and unskilled workers as well as for individuals with a stronger health condition.

Our results are smaller than the ones found in the previous literature. We believe that part of the differences in the estimates may be due to the fact that we are able to solve the endogeneity problem found in other papers by using as comparison group individuals that suffer from a sudden health shock (an accident) which are clearly not disabled before entering the DI system. Even if different in size, our results reinforce the findings of previous papers in the literature which find an important drop both in earnings and employment before onset of the disabling condition as well as the occurrence of these differences in the last five years before becoming disabled.

The results of our paper are important for policy-makers as they suggest that taking the last years of labour market experience as a base to calculate the amount and eligibility conditions of DI benefits may not reflect the real wage and employment pattern of non-disabled individuals if they suffer from an ordinary illness that is making them incur in important earnings and employment losses long before being accepted in the DI system. 


\section{Appendix}

\section{The Spanish Disability System:}

Table A1. Summary of the parameters to calculate permanent disability pensions.

\begin{tabular}{|c|c|c|c|}
\hline & Ordinary Illness & $\begin{array}{l}\text { Work-unrelated } \\
\text { Accident }\end{array}$ & $\begin{array}{l}\text { Work-related } \\
\text { Accident or } \\
\text { Professional Illness }\end{array}$ \\
\hline \multirow[t]{2}{*}{ Eligibility } & $\begin{array}{l}\text { Age }>=31: \\
\text { Contributed } 1 / 4 \quad \text { time } \\
\text { between } 20 \text { years old and } \\
\text { disabling condition. } \\
\text { Minimum of } 5 \text { years }\end{array}$ & \multirow[t]{2}{*}{$\begin{array}{c}\text { No minimum } \\
\text { contributory period } \\
\text { required }\end{array}$} & \multirow[t]{2}{*}{$\begin{array}{l}\text { No minimum } \\
\text { contributory period } \\
\text { required }\end{array}$} \\
\hline & $\begin{array}{l}\text { Age <30: } \\
\text { Contributed } 1 / 3 \text { time } \\
\text { between } 16 \text { years old and } \\
\text { disabling condition. No } \\
\text { minimum number of years } \\
\text { required }\end{array}$ & & \\
\hline $\begin{array}{l}\text { Regulatory } \\
\text { Base }\end{array}$ & $\begin{array}{l}\text { Average wage last } 8 \text { years of } \\
\text { work }\end{array}$ & $\begin{array}{l}\text { Average annual wage } \\
\text { of } 24 \text { months within } \\
\text { the last } 7 \text { years of } \\
\text { work }\end{array}$ & $\begin{array}{l}\text { Average wage last } \\
\text { year of work }\end{array}$ \\
\hline \multirow{3}{*}{$\begin{array}{l}\text { Percentage } \\
\text { applied to } \\
\text { the } \\
\text { regulatory } \\
\text { base }\end{array}$} & \multicolumn{3}{|c|}{$\begin{array}{l}\text { Partial Disability: } 55 \% \\
\text { Individuals older than } 55 \text { with difficulties to find a job due to lack of } \\
\text { education or characteristics of the social and labor market of the region where } \\
\text { they live: } 75 \%\end{array}$} \\
\hline & \multicolumn{3}{|l|}{ Total Disability: $100 \%$} \\
\hline & \multicolumn{3}{|l|}{ Severe Disability: $100 \%+50 \%$} \\
\hline
\end{tabular}

The disability system in Spain distinguishes between two types of permanent disability benefits: i) contributory, which are given to individuals who have generally contributed to the Social Security system before the onset of the disabling condition; ii) and noncontributory, which are given to individuals who are assessed to be disabled but have never contributed to the Social Security system (or do not reach the minimum contributory requirement to access the contributory system). Non-contributory disability benefits are means-tested and managed at the regional level. ${ }^{14}$

The size of the non-contributory system is relatively small compared to the contributory system $(197,126$ individuals received non-contributory disability benefits in 2009 , while 920,860 received contributory benefits during the same year). The amount of benefits received is also smaller in the non-contributory case (the average non-contributory

\footnotetext{
${ }^{14}$ Income is evaluated yearly. The income threshold in 2010 was set at 4,755.80 Euros/year for an individual living alone. This amount is adjusted if the individual lives with other members.
} 
pension is 417.09 Euros/month compared to an average contributory disability pension of 831.49 Euros/month). As we want to assess the effect of disability on wages we focus only on the permanent contributory disability system in Spain.

As seen in Table A1 above, with respect to eligibility, the number of years of contributions required depends on the age of the onset of the disabling condition for common illness while there are no contributory requirements if the health impairment is due to either an accident or an occupational illness.

The number of years included in the regulatory base depends on the source of the disability; for common illness the regulatory base is calculated by dividing by 112 the wage in the last 96 months ( 8 years) before becoming disabled. When the source of the disability is a work-unrelated accident, the regulatory base is calculated by dividing by 28 the wage in the last 24 months before becoming disabled. The individual can choose these 24 months from the last 7 years of work. For work-related accident or professional illness, the regulatory base is calculated by dividing by 12 the wage in the last 365 days before becoming disabled. ${ }^{15}$

\footnotetext{
${ }^{15}$ There was a reform in the calculation of the level of disability benefits for ordinary illness introduced in 2008. After the reform, there was a percentage that depended on the number of years contributed to the system that was multiplied by the regulatory base. As this change only affects individuals whose source of the disability is an ordinary illness, which could have an effect on the incentives to enter the DI system for this group of workers, in the robustness check section we will perform the same analysis but excluding the years after 2008 in order to have a sample period without any important reform of the DI system.
} 
Table A2: Wage path for both disability types in the years before DI (full estimation)

\begin{tabular}{|c|c|c|c|}
\hline \multicolumn{2}{|c|}{ Variable } & \multirow{2}{*}{$\frac{\text { Coefficient }}{0.368}$} & \multirow{2}{*}{$\begin{array}{c}\text { Standard error } \\
0.009\end{array}$} \\
\hline Sex & Men & & \\
\hline Age that became disabled & & 0.007 & 0.0005 \\
\hline \multirow{3}{*}{ Eduacation } & Secondary & 0.141 & 0.008 \\
\hline & Tercery & 0.338 & 0.012 \\
\hline & Post-graduate & 0.466 & 0.032 \\
\hline \multirow[t]{2}{*}{ Professional category } & $\begin{array}{r}\text { Semi-skilled } \\
\text { workers }\end{array}$ & 0.111 & 0.005 \\
\hline & Skilled Workers & 0.247 & 0.008 \\
\hline \multirow[t]{5}{*}{ Activity } & Industry & 0.215 & 0.010 \\
\hline & Construction & 0.162 & 0.012 \\
\hline & $\begin{array}{r}\text { Trade, Transport } \\
\text { and Hotels } \\
\text { Public }\end{array}$ & 0.211 & 0.013 \\
\hline & Administration & 0.215 & 0.025 \\
\hline & Finance & 0.166 & 0.024 \\
\hline Part-time & & 0.558 & 0.006 \\
\hline Spanish & & 0.179 & 0.033 \\
\hline Years since DI & -9 & 0.020 & 0.013 \\
\hline \multirow[t]{8}{*}{ (Disabled by accident) } & -8 & 0.030 & 0.012 \\
\hline & -7 & 0.055 & 0.012 \\
\hline & -6 & 0.076 & 0.012 \\
\hline & -5 & 0.119 & 0.012 \\
\hline & -4 & 0.135 & 0.012 \\
\hline & -3 & 0.172 & 0.011 \\
\hline & -2 & 0.199 & 0.011 \\
\hline & -1 & 0.180 & 0.012 \\
\hline Years since DI & -9 & 0.017 & 0.004 \\
\hline \multirow[t]{8}{*}{ (Disabled common illness) } & -8 & 0.037 & 0.004 \\
\hline & -7 & 0.055 & 0.004 \\
\hline & -6 & 0.072 & 0.004 \\
\hline & -5 & 0.094 & 0.004 \\
\hline & -4 & 0.112 & 0.003 \\
\hline & -3 & 0.125 & 0.003 \\
\hline & -2 & 0.135 & 0.003 \\
\hline & -1 & 0.109 & 0.004 \\
\hline Number of observations & & 252,496 & \\
\hline
\end{tabular}


Table A3: Average difference in monthly wages between disabled by accident and disabled by ordinary illness before DI. Robustness check.

\begin{tabular}{|c|c|c|c|c|}
\cline { 2 - 5 } \multicolumn{1}{c|}{} & \multicolumn{2}{|c|}{ Propensity score matching } & \multicolumn{2}{c|}{$\begin{array}{c}\text { Propensity score matching with } \\
\text { DID }\end{array}$} \\
\hline Years \\
since DI & $\begin{array}{c}\text { Kernel } \\
\text { Matching }\end{array}$ & $\begin{array}{c}\text { Stratification } \\
\text { matching }\end{array}$ & $\begin{array}{c}\text { Kernel } \\
\text { Matching }\end{array}$ & $\begin{array}{c}\text { Stratification } \\
\text { matching }\end{array}$ \\
\hline-7 & $-2,42$ & 1,33 & 2,51 & 2,66 \\
& $(10.17)$ & $(10.17)$ & $(8.12)$ & $(5.29)$ \\
\hline-6 & $-8,85$ & $-3,13$ & $-25,58$ & $-2,79$ \\
& $(10.17)$ & $(10.44)$ & $(7.27)$ & $(6.68)$ \\
\hline-5 & $-0,57$ & $-4,78$ & 3,97 & 3,51 \\
& $(10.17)$ & $(10.76)$ & $(9.18)$ & $(7.52)$ \\
\hline-4 & 6,79 & 5,57 & 11,06 & 9,76 \\
& $(10.17)$ & $(10.86)$ & $(11.17)$ & $(8.06)$ \\
\hline-3 & 8,36 & 8,18 & $20,13 *$ & $17,75 *$ \\
& $(10.17)$ & $-11,03$ & $(10.81)$ & 8,35 \\
\hline-2 & $\mathbf{9 , 8 6} *$ & $\mathbf{9 , 9 5} *$ & $\mathbf{2 2 , 8 9} *$ & $\mathbf{1 8 , 6 6} *$ \\
& $(10.17)$ & $(10.18)$ & $(9.74)$ & $(8.53)$ \\
\hline-1 & $\mathbf{2 5 , 5 1} * *$ & $\mathbf{3 3 , 3 7} * *$ & $\mathbf{2 9 , 0 1} * *$ & $\mathbf{3 2 , 4 4} * *$ \\
& $(10.17)$ & $(11.27)$ & $(11.24)$ & $(8.67)$ \\
\hline
\end{tabular}

Note: Money figures are expressed in 2010 euros. Bootstrapped standard errors in parentheses. 
Table A4: Difference in employment between disabled by accident and disabled by ordinary illness before DI. Robustness check.

\begin{tabular}{|c|c|c|c|c|}
\cline { 2 - 5 } \multicolumn{1}{c|}{} & \multicolumn{2}{|c|}{ Propensity score matching } & \multicolumn{2}{c|}{$\begin{array}{c}\text { Propensity score matching with } \\
\text { DID }\end{array}$} \\
\hline Years \\
since DI & $\begin{array}{c}\text { Kernel } \\
\text { Matching }\end{array}$ & $\begin{array}{c}\text { Stratification } \\
\text { matching }\end{array}$ & $\begin{array}{c}\text { Kernel } \\
\text { Matching }\end{array}$ & $\begin{array}{c}\text { Stratification } \\
\text { matching }\end{array}$ \\
\hline-7 & 0.014 & 0.021 & 0.022 & 0.020 \\
& $(0.011)$ & $(0.011)$ & $(0.017)$ & $(0.017)$ \\
\hline-6 & $\mathbf{0 . 0 1 9} *$ & 0.020 & $\mathbf{0 . 0 2 1} * *$ & $\mathbf{0 . 0 1 7} *$ \\
& $(0.008)$ & $(0.009)$ & $(0.008)$ & $(0.008)$ \\
\hline-5 & $\mathbf{0 . 0 1 6} *$ & $\mathbf{0 . 0 3 9} * *$ & $\mathbf{0 . 0 4 0} * * *$ & $\mathbf{0 . 0 3 8} * * *$ \\
& $(0.008)$ & $(0.008)$ & $(0.009)$ & $(0.009)$ \\
\hline-4 & $\mathbf{0 . 0 3 8} * * *$ & $\mathbf{0 . 0 4 4} * * *$ & $\mathbf{0 . 0 4 5} * * *$ & $\mathbf{0 . 0 4 3} * * *$ \\
& $(0.008)$ & $(0.008)$ & $(0.010)$ & $(0.009)$ \\
\hline-3 & $\mathbf{0 . 0 4 2} * * *$ & $\mathbf{0 . 0 5 9} * * *$ & $\mathbf{0 . 0 6 1} * * *$ & $\mathbf{0 . 0 5 6} * * *$ \\
& $(0.007)$ & $(0.006)$ & $(0.010)$ & $(0.009)$ \\
\hline-2 & $\mathbf{0 . 0 5 6} * * *$ & $\mathbf{0 . 0 8 7} * * *$ & $\mathbf{0 . 0 8 8} * * *$ & $\mathbf{0 . 0 8 3} * * *$ \\
& $(0.007)$ & $(0.007)$ & $(0.010)$ & $(0.010)$ \\
\hline-1 & $\mathbf{0 . 0 8 3} * * *$ & $\mathbf{0 . 0 9 1} * * *$ & $\mathbf{0 . 0 9 2} * * *$ & $\mathbf{0 . 0 8 7} * * *$ \\
& $(0.006)$ & $(0.006)$ & $(0.011)$ & $(0.010)$ \\
\hline
\end{tabular}

Note: Bootstrapped standard errors in parentheses. Treated and control individuals are matching using the nearest neighbor matching approach. 


\section{References}

Abadie A, Drukker D, Herr H, Imbens G. 2004. Implementing matching estimators for average treatment effects in Stata. Stata Journal 4: 290-311.

Abadie A, Imbens G. 2002. Simple and bias-corrected matching estimators for average treatmen efects in STATA. Stata Journal 1 (1): 1-18.

Becker S, Ichino A. 2002. Estimation of average treatment effects based on propensity scores. Stata Journal 2(4): 358-377.

Blundell R, Costa Dias M. 2002. Alternative approaches to evaluation in empirical microeconometrics. Portuguese Economic Journal 1: 91-115.

Bonhomme, S., and L. Hospido (2009): "Using Social Security Data to Estimate Earnings Inequality," Mimeo.

Bound, J. 1989. The Health and Earnings of Rejected Disability Insurance Applicants. American Economic Review, 79 (3), 482-503.

Cervini M, Silva J.I, Vall Castello J. 2012. Estimating the Income Loss of Disabled Individuals: The Case of Spain. IZA Discussion Papers 6752.

Charles, K. K. 2003. The Longitudinal Structure of Earnings Losses among WorkLimited Disabled Workers, Journal of Human Resources, 38(3), 618-46.

Chen S, Van Der Klaauw W. 2008. The Work Disincentive Effects of the Disability Insurance Program in the 1990s. Journal of Econometrics, 142(2), 757-84.

Contoyannis P, Rice N. 2001. The impact of health on wages: Evidence from the British Household Panel Study. Empirical Economics 26 (4): 599-622.

French E, Song J. 2014. The Effect of Disability Insurance Receipt on Labor Supply. American Economic Journal: Economic Policy, 6(2), 291-337.

Garcia Gomez P, López Nicolás A. 2006. Health Shocks, Employment and Income in the Spanish Labour Market. Health Economics 15: 997-1009.

García-Gómez P, Hans van Kippersluis, Owen O'Donnell and Eddy van Doorslaer (2013). Long-Term and Spillover Effects of Health Shocks on Employment and Income. The Journal of Human Resources 48 (4): 873-909.

Halla M, Zweimüller M. 2013. The Effect of Health on Earnings: Quasi-Experimental Evidence from Commuting Accidents. Labour Economics 24: 23-38.

Heckman J, Hotz J. 1989. Choosing among alternative methods for estimating the impact of social programs: The case of manpower training. Journal of the American Statistical Association 84: 862-874.

Heckman J, Ichimura H, Todd P. 1997. Matching as an econometric evaluation estimator: evidence from evaluating a job training program. Review of Economics Studies 64: 605-654.

Jolly N.A. 2013. The Impact of Work-Limiting Disabilities on Earnings and Income 
Mobility. Applied Economics 45(36): 5104-5118.

Kidd M, Sloane P, Ferko I. 2000. Disability and labour market: an analysis of British males. Journal of Health Economics 19: 961-981.

Lechner M, Vazquez-Alvarez R. 2011. The Effect of Disability on Labour Market Outcomes in Germany. Applied Economics 43: 389-412.

Lundborg P, Nilsson M, Vikström J. 2011. Socioeconomic Heterogeneity in the Effect of Health Shocks on Earnings: Evidence from Population-Wide Data on Swedish Workers. IZA Working Papers No.6121.

Maestas N, Mullen KJ, Strand A. 2013. Does Disability Insurance Receipt Discourga Work? Using Examiner Assignment to Estimate Causal Effects of SSDI Receipt, American Economic Review, 103 (5), 1797-1829.

Malo, M.A. and Pagán, R. (2012): "Wage differentials and disability across Europe: Discrimination and/or lower productivity", International Labour Review, 151(1-2): 4360.

Marie O, Vall-Castello J. 2012. The Employment Effects of Increasing Disability Benefits: A Regression Discontinuity Approach. Journal of Public Economics, 96(1-2), 198-210.

Mok, W. K.C., Meyer, B. D., Charles, K. K. and Achen, A. C. 2008. A Note on the Longitudinal Structure of Earnings Losses among Work-Limited Disabled Workers. Journal of Human Resources, 43(3), 721-8.

OECD. 2009. Sickness, Disability and Work: Keeping on Track in the Economic Downturn: Background Paper.

Rubin DB. 1973. Matching to remove bias in observational studies. Biometrics 29: 159183.

Rubin DB. 1974. Estimating casual effects of treatments in randomised and nonrandomised studies. Journal of Educational Psychology 66: 688-701.

Rosenbaum P, Rubin DB. 1983. The central role of the propensity score in observational studies for causal effects. Biometrika 70: 41-55.

Rosenbaum P, Rubin DB. 1984. Reducing bias in observational studies using subclassification on the propensity score. Journal of American Statistical Association 79: $516-524$.

Von Wachter T, Song J, Manchester J. 2011. Trends in Employment and Earnings of Allowed and Rejected Applicants to the Social Security Disability Insurance Program. American Economic Review, 101 (7), 3308-29.

Walker I, Thompson A. 1996. Disability, wages and labour force participation: Evidence from UK panel data. Keele Department of Economics Working Paper No. 96/14. 